\title{
МЕНЕДЖМЕНТ
}

УДК 331.442

DOI: https://doi.org/10.26642/jen-2020-1(91)-66-74

\author{
О.В. Громцева, аспірант \\ В.В. Стрюков, аспірант \\ Дніпровський національний університет імені О.Гончара
}

\section{Перспективи застосування методики «Кайдзен» під час змін у медичній галузі України}

(Представлено: д.е.н., проф. Гринько Т.В.)

\begin{abstract}
У наш час - час змін - проходить прочес оновлення не тільки сфери бізнесу, але й державної сфери. Державні підприємства мають встигати підлаштовуватися під ситуаџію задля того, щуоб залучити кліснта. У цій статті було вивчено сутність методики «Кайдзен» у контексті застосування в медичних закладах Украӥни під час змін у структурі медичної галузі. Для вирішення поставлених завдань у роботі використовувалися такі загальнонаукові методи дослідження, як опис, порівняння, аналіз, синтез та деякі інші. Було детально вивчено, у чому полягає різниця японського національного характеру із украйнським у контексті впровадження методики «Кайдзен» на украӥнських підприємствах. Система «Кайдзен» побудована, насамперед, на взаємодї між людьми. Саме тому, насамперед, необхідно заздалегідь опраџьовувати міжособистісні контакти у медичних установах. Було визначено, щзо методика «Кайдзен» може застосовуватися у різних сферах та галузях, та, насамперед бути застосована у медичній сфері Украйни. Вивчення було проведено на первинному рівні, тому в подальшому тема може бути розкрита більше. Також слід зауважити, щчо особливістю надання медичних послуг є постійний контакт із клієнтами, тому медичний персонал має розуміти, як вислухати побажання пацієнтів та використати найбільи ицінні ідеї для покращення подальшої роботи усієї медичної структури, чим і навчає користуватися методика «Кайдзен». Було визначено основні принципи впровадження методики у медичній сфері, але варто зауважити, щзо тема є дуже глибокою і потребує подальшого вивчення.
\end{abstract}

Ключові слова: «Кайдзен»; методика; система управління; медична установа; вдосконалення; підвищення продуктивності.

Актуальність теми. В наш час бізнес в Україні продовжує перехід від планової до ринкової економіки. Власники багатьох підприємств намагаються збільшити капіталізацію, але у часи кризи мало хто може похвалитися засобами для інноваційного оновлення, яке потребує більших інвестицій. У таких умовах розглядаються усі методи розвитку системи, які не призводять до різких та раптових витрат. Отже, набуває популярності використання методу «Кайдзен», який свідчить досвід підприємств Японії, допомагає впоратися з проблемами та досягти приголомшливих результатів без великих інвестицій. «Кайдзен» дозволяє у багато разів збільшити якість та продуктивність, зменшити втрати та ризики, спростити організаційну структуру, а також збільшити гнучкість організації. Його сутність у тому, що щоденні покращення можуть бути невеликими та кожне 3 них окремо, можливо, буде не помітним, але у сукупності вони дадуть значний ефект [1, с. 312].

Вже 3 січня 2018 р. Міністерство охорони здоров'я України розпочало впровадження змін в охороні здоров'я [2]. Практика управління сферою охорони здоров'я в умовах демократизації суспільного життя і становлення ринкової економіки, демографічна ситуація та стан здоров'я населення України свідчать про неефективність традиційних організаційно-управлінських засобів і заходів. Необхідні негайні реформи діючої системи надання медичних послуг та пошук нових шляхів вирішення питань управління i форм врядування, що відповідають складності сучасних проблем та потребам часу [3].

Аналіз останніх досліджень і публікацій. Система кайдзен-менеджменту у сучасній Україні є недостатньо висвітленою темою. Переважно ця система вивчалася вченими 3 інших країн, такими як: М.Імаї [4], К.Коб'єлл [5], Р.Маурер [6], В.В. Качалай [7], Є.В. Садченко [8], Є.В. Печериця, М.I. Шевченко [9] та іншими. Дослідження, які присвячені менеджменту українських медичних установ, зустрічаються частіше. Дослідження Є.Богодістова із колегами [10] присвячене проблемам реформування первинної ланки медичних установ в Україні. Данченко О.Б. та Лепський В.В. [11] присвятили свою роботу вивченню питань взаємозв’язку медичних проектів проектно-орієнтованого медичного закладу із зовнішнім середовищем, який, на думку авторів, забезпечується через стратегію розвитку медичного закладу. Організаційно-психологічні аспекти роботи лікаря з менеджментом лікарні були розглянуті у роботі таких вчених, як Г.М. Урсол [12], Л.В. Гринів та Т.В. Пушик [13].

(C) О.В. Громцева, В.В. Стрюков, 2020 
Вони провели аналіз ефективності менеджменту поліклінічних закладів у системі охорони здоров'я та освітлення компетенції організаторів охорони здоров’я і шляхів їх формування. Громцева Д.К. та Крупський О.П. вивчали проблеми формування культури безпеки працівників медичного закладу [14]. Водночас практично відсутні дослідження кайдзен-стратегій у сфері менеджменту українських підприємств.

Мета статті визначити, чи можливо використовувати систему «Кайдзен» у підприємствах медичної сфери України та як вона може посприяти підвищенню якості медичних послуг.

Викладення основного матеріалу дослідження. Необхідно зауважити, що усі процеси змін у сфері охорони здоров'я проходять повільніше ніж в інших галузях. Але разом з цим, різні медичні заклади постійно намагаються використовувати нові сучасні управлінські технології та концепції. Задля стійкого розвитку стає актуальним питання про необхідність розробки системи безперервних покращень усіх процесів організації. Такий підхід до управління пропонує японська концепція «Кайдзен», яка давно знайшла своє використання серед японських менеджерів та поступово впроваджується в усьому світі [15]. Отже, спочатку з'ясуємо, що саме мається на увазі під словом «кайдзен». Кайдзен - це процес безперервного вдосконалення приватного, сімейного, суспільного та трудового життя [4]. В економічних відносинах кайдзен - це стратегія вдосконалення, яка орієнтована на споживача, тобто задоволеність покупця розглядається як базовий критерій ефективності діяльності [16, с. 20].

Термін «кайдзен»- японське слово, яке складається з двох частин: kai, який має на увазі «зміну», i zen, що означає «добре» $[17,18]$.

Концепція «Кайдзен» як філософія управління була запропонована японцем Масаакі Імаі у 1986 р. i швидко набула широкої популярності серед підприємців. [5]. Логіка «Кайдзен» була вперше представлена у 2006 р. у праці Масаакі Імаі: «Кайдзен - ключ до японського конкурентоздатного успіху». Автор дає таке визначення: «Кайдзен означає вдосконалення. У контексті цієї книги кайдзен розуміється як безперервний процес вдосконалення, у який залучені усі - вищі менеджери, менеджери середньої ланки та робітники» [4].

Цілі «Кайдзен»:

1. Зниження собівартості.

2. Зменшення термінів виконання замовлення.

3. Збільшення оборотного капіталу компанії за рахунок зниження рівня запасів ресурсів, які використовуються.

4. Підвищення кваліфікації усього персоналу.

5. Впровадження гнучких виробничих технологій, які дозволяють у короткий строк реагувати на запит покупця - поставка продукції у необхідний термін, у необхідній кількості [19].

Японці першими усвідомили важливість кращого розуміння потреб клієнта та необхідність системного підходу до аналізу його очікувань для виявлення ступеня їх впливу на технічні характеристики створюваного продукту i забезпечення у кінцевому результаті максимальної цінності продукту для споживача. Вони зуміли розробити систему створення та удосконалення продукту відповідно до з вимог та пріоритетів ринку, досягнувши у наслідку значних покращень якості, зменшення витрат часу та вартості продукту - ключових факторів задоволення споживача та успіху компанії [20].

Саме по собі вчення «Кайдзен» універсальне. Воно легко може бути застосоване як у роботі окремої ланки, так і для вдосконалення усієї системи величезної корпорації. Це стиль мислення у японських корпораціях. Компанії намагаються розвивати його у своїх працівників. Це шлях до саморозвитку та самовдосконалення як окремої особистості, так і частини корпорації, у якій працює людина.

За деякими даними, близько 50 \% часу медичного персоналу не використовується напряму для пацієнта. $€$ необхідним перехід на персоналізовану медицину, де пацієнт отримує допомогу в необхідний час та у необхідному місці. Сьогодні таку систему почали впроваджувати завдяки реформуванню медичної сфери України. Лікарні мають бути розташовані таким чином, щоб пацієнт не витрачав свій час на переїзди та очікування, які, у свою чергу, призводять до значних фінансових витрат та зниження ефективності самого лікування [21].

Перерахуємо переваги «Кайдзен»:

1. Цю систему можна використовувати для будь-яких підприємств;

2. Зміни не видно зовні, оскільки крок змін дуже невеликий;

3. Система не потребує значних фінансових витрат на реструктуризацію компанії, оскільки основні зміни відбуваються на місцях;

4. Залученість персоналу у процес змін/покращень (якщо мета змін правильно донесена до співробітників);

5. Покращення якості продукції, відношень, сервісу [22]. 
Підходи кайдзен-менеджменту різко відрізняються від прийнятих на Заході методів управління. У Японії особливу увагу приділяють людям та процесу виробництва, у той час як на Заході керівництво компаній орієнтується на продукт та результат.

Основа методу складається з п'яти ключових елементів, або п'яти $\mathrm{S}$, які можна застосувати й у роботі медичного закладу. Отже, розглянемо ці ключові елементи стосовно праці у медичному закладі:

- сортування (японське слово - Seiri) - відокремлення часто використовуваних і невикористовуваних предметів праці на робочому місці, усунення невикористовуваних;

- впорядкування (японське слово - Seitton) - впорядкування невикористовуваних речей. Ставити усе на свої місця та організовувати матеріали відповідно до того, як часто вони використовуються. Рекомендується використання візуальних засобів для полегшення розуміння системи;

- сяйво (японське слово - Seiso) - підтримка обладнання і машин у чистоті. Не допускати забруднення, порушень;

- стандартизація (японське слово - Seiketsu) - поширення поняття чистоти на особу працівника i постійне дотримання попередніх трьох кроків;

- підтвердження (японське слово - Shitsuke) - дисципліна, основним принципом якої є «створи самого себе» і постійна практика попередніх кроків. Формування звичок на робочому місці задля дотримання визначених стандартів [17, с. $602 ; 23$, с. 477].

Масаакі Імаі представляв «Кайдзен» як стратегію-парасольку, яка об'єднує багато відомих методів оптимізації виробництва і підвищення ефективності. «Парасолька» кайдзен - чітке уявлення про те, що відбувається у японській промисловості. Кайдзен - це «парасолька», під якою сховалася більша частина цих «унікальних для Японії» практик, які отримали популярність у всьому світі. Основне значення загального контролю якості (TQC) у тому, що ці концепції допомогли японським фірмам сформувати мислення, яке орієнтоване на процес, та розробити стратегії безперервного вдосконалення, причому, у цей процес залучені працівники на усіх рівнях організованої ієрархії (рис. 1).

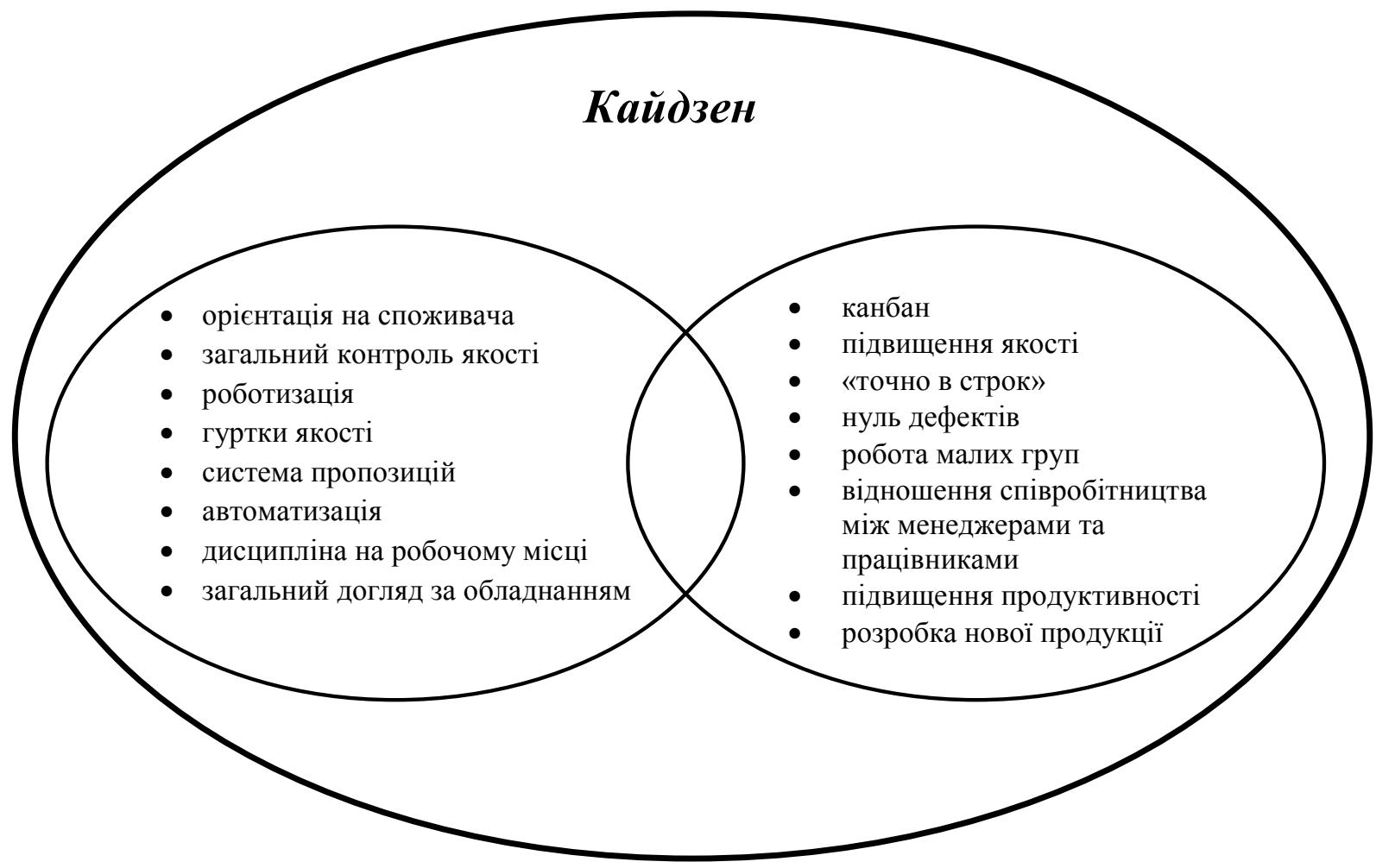

Рис. 1. Стратегія «Кайдзен» [4]

«Кайдзен» являє собою вираження, насамперед, національно-релігійних ідей, їх втілення в економічній сфері. Риси національного японського характеру зокрема враховують: 
- релігійне відношення до праці та продукту своєї праці (філософія «монодзукурі» - підтримання балансу між різними елементами буття, в економіці - акт створення матеріальних та духовних цінностей);

- найвищу відповідальність та працьовитість;

- відкритість чужому досвіду та знанням (концепція безперервного навчання як особливість японського менеджменту);

- групову орієнтацію та узгодженість дій, схильність до співпраці. Діяльність кожного впливає на стабільність системи, тому не буває незначної роботи, кожен є відповідальним за підтримку гармонічної рівноваги; акцент не стільки на персональному добробуті, скільки на добробуті нації; почуття «гирі»потреба виконувати борг вдячності один перед одним [24].

- сінтоїстське сприйняття світу (сприйняття себе як частини цілого, творення як вираз подяки до богів, нові знання як вираження їх прихильності, специфіка світосприйняття у аспекті долі людини після смерті змушувала усі сили віддавати перетворенню «земних» реалій), гармонійно вплетене у навчання Будди;

- підвищення кваліфікації як самоціль (тобто вдосконалення майстерності - особистий борг кожного, ніяк не пов'язаний із матеріальною стимуляцією);

- потреба у моральному задоволенні від праці [19, с. 21].

Якщо порівняти риси японського національного характеру з українськими, то можна виявити декілька подібних рис, а саме: відповідальність, працездатність, рішучість, спрямованість на результат. Але, на жаль, відмінностей набагато більше, ніж спільних рис. Насамперед, українці відрізняються стійким індивідуалізмом, що погано може відобразитися на роботі у команді. Український індивідуалізм, на противагу європейському, має внутрішньо спрямований характер із переважанням емоційно-почуттєвого переживання над холодною розсудливістю. Тому українці здебільшого не налаштовані на дієву, активну боротьбу за краще життя, не прагнуть масової згуртованості [23, с. 57].

Національний менталітет надовго закріпив пасивну позицію народу щодо необхідності й можливості самовизначення, особливо це стосується економічної сторони життя людини, тобто їі трудової діяльності, трудового менталітету та трудової поведінки. В українців присутній дух авантюризму, підприємництва, ініціативності для досягнення власних цілей, але водночас, терплячість та намагання не робити поспішних кроків й тим самим переборювати негативні явища у житті [25, с. 80-81].

Оскільки «Кайдзен» працює 3 людським опором до змін, першим кроком є необхідність ментально підготувати працівників прийняти запропоновані інструменти «Кайдзен» перед тим, як почнеться процес впровадження. Необхідно ввести у курс справи кожного працівника, щоб досягнути максимального ефекту від концепції, яка впроваджується. Як попередні заходи необхідно виділити час для обговорення філософії та їі переваг [15].

«Кайдзен» є геніальною управлінською розробкою, яка змушує національний колективізм та релігійні традиції сприяти економічному диву. «Класичний» Кайдзен описаний у працях Масаакі Імаі. Основна ідея полягає у деякому протиставленні традицій японського та американського напрямів менеджменту. «Кайдзен» починається з проблеми, чи, радше, з визнання того, що вона існує. Якщо проблеми не виявлено, отже, немає потреби в удосконаленні. У цьому відмінність «Кайдзен» від традиційного менеджменту американської та європейської моделі, а саме - вирішення всіх проблемних ситуацій безпосередньо в місці їх виникнення, тобто там, де продукту (послузі) додається споживча цінність.

Якщо у традиціях західного менеджменту - впровадження інновацій, то східний менеджмент робить акцент на вдосконаленні як концепції підвищення ефективності будь-якого процесу у сфері економіки, політики і навіть релігії. У таблиці 1 наведено відмінності західного та східного підходів до менеджменту.

Таблиия 1

Відмінності японського підходу «Кайдзен» і традиційного менеджменту у західних компаніях [26]

\begin{tabular}{|c|c|c|}
\hline Показник & Кайдзен & Західний стиль менеджменту \\
\hline Орієнтація на & Процес & Резултат \\
\hline Розвиток & $\begin{array}{c}\text { Поступовий, що проявляєтья } 3 \\
\text { часом, іноді плюс інновації }\end{array}$ & $\begin{array}{c}\text { Стрибкоподібний, тільки за рахунок } \\
\text { інновацій }\end{array}$ \\
\hline Ресурси & Бережливе витрачання ресурсів & $\begin{array}{c}\text { Нераціональне витрачання ресурсів - доки } \epsilon \\
\text { прибуток, немає сенсу оптимізувати витрати }\end{array}$ \\
\hline Відношення у колективі & $\begin{array}{c}\text { Взаємодопомога, підтримка, обмін } \\
\text { знаннями }\end{array}$ & $\begin{array}{c}\text { Індивідуалізм, конкуренція між } \\
\text { особистостями та підрозділами }\end{array}$ \\
\hline Керівництво & $\begin{array}{c}\text { Лідер, який наділений авторитетом } \\
\text { та досвідом }\end{array}$ & Керівник, наділений владою \\
\hline $\begin{array}{c}\text { Сприятливе середовище для } \\
\text { застосування }\end{array}$ & $\begin{array}{c}\text { Повільне зростання економіки } \\
\text { через нестачу ресурсів }\end{array}$ & Економічний бум, ресурси у надлишку \\
\hline Перспектива & Довгострокова & Короткострокова \\
\hline
\end{tabular}


Ефективне управління процесами на основі концепції «Кайдзен» активно використовують провідні іноземні компанії, серед них Toyota Motors Corporation [18], Canon [27], Honda, Nissan [28], Scrum [29] та багато інших. Окремі принципи концепції кайдзен простежуються на таких великих підприємствах, як «Лукойл» та «Камаз» [30].

Прагнення до ідеалу підкріплюється п’ятьма системами формування відносин між людиною та організацією:

- система довічного найму;

- система навчання на робочому місці;

- система ротації;

- система гідностей;

- система винагород [5].

Система покращення «Кайдзен» потребує постійних зусиль усіх учасників процесу. Ось чому жоден учасник процесу не має залишитися осторонь від цієї роботи як через персональну незацікавленість, так $\mathrm{i}$ через ненадану йому можливість бути залученим. «Кайдзен» надає перевагу лідерству в протидію західному формальному керівництву. Японські менеджери заслуговують авторитет не табличкою на дверях кабінету, а своїми знаннями, досвідом, прийнятими рішеннями, особистим прикладом. Вони відкриті для підлеглих, багато часу проводять на виробництві, вільно спілкуються із співробітниками будь-якого рівня. Без підтримки топ-менеджменту впровадити «Кайдзен» у компанії неможливо: цілі 3 вдосконалення встановлюються на вищому рівні та розгортаються зверху вниз. Реалізація намічених планів потребує прийняття рішень та інвестицій. Чим вище менеджер за ієрархією, тим більше дій із самовдосконалення від нього очікують.

Від ефективної та успішної взаємодії залежить успіх медичної організації, досягнення загальної цілі. Цей принцип має бути зрозумілим для працівників будь-якої медичної установи: як приватної, так $\mathrm{i}$ державної. Кожен працівник має розуміти, з якими людьми він безпосередньо взаємодіє, яким чином його праця пов'язана із працею інших людей, які існують засоби зв'язку між колегами тощо [15].

Саме тому система «Кайдзен» здійснюється за рахунок створення та постійної роботи так званих кайдзен-команд [30]. Згідно із завданнями, які вони вирішують, можна виокремити 5 основних видів команд:

1. Постійні команди - ці команди працюють кожен день. У склад команд входять спеціалісти (робітники, службовці), які виконують роботу на місцях.

2. Команди по вирішенню проблем, які виникли, - формуються для пошуку рішення конкретної проблеми по роботі. До команди входять учасники з декількох постійних команд. Загальна кількість учасників такої команди становить, як правило, від шести до восьми людей. Після того, як рішення знайдене, команда розформовується.

3. Кросс-функційні команди - формуються для оцінки існуючих процесів організації та пошуку можливостей з їх покращення. До команд входять рядові спеціалісти та керівники з різних підрозділів.

4. Команди з реалізації рішень - формуються для впровадження розроблених покращених процесів. Ці команди складаються з учасників постійних команд, команд за вирішенням проблем, які виникли та кросфункційних команд.

5. Малі групи - формуються для розробки, впровадження та застосування специфічних або нових процесів. До команд входять спеціалісти нижчої ланки (робітники, виконавці) та керівники підрозділів 3 постійних команд та команд з вирішень проблем, які виникли.

Робота команд (за виключенням постійних) здійснюється впродовж кайдзен-сесій, що тривають від 2 до 5 днів. Проведення кожної сесії спрямоване на вирішення будь-якого конкретного бізнес-завдання [32].

Для більш ефективного функціонування кайдзен-груп необхідні щотижневі наради з обговорення таких питань:

- поточний стан справ у підрозділі (звіт);

- виявлені під час внутрішніх аудитів невідповідності (при наявності системи менеджменту якості);

- цілі та завдання щодо поліпшення робочих процесів;

- які кайдзен-інструменти будуть застосовані;

- конкретний план дій [33].

Концепція «Кайдзен» $е$, насамперед, довгостроковою стратегією розвитку підприємства, що має певні цілі і використовує в процесі їх досягнення кожного окремого члена персоналу підприємства. Отже, ця концепція залучає у процес управління увесь трудовий колектив, кожен член якого має певні функції:

- вище керівництво - розробка довгострокової стратегії розвитку підприємства на основі принципів «Кайдзен», сприяння іiї реалізації; 
- керівники середньої ланки - реалізують цілі, визначені вищим керівництвом, застосовують концепцію «Кайдзен» у власній діяльності, сприяють формуванню «кайдзен-мислення» у робочого персоналу у процесі їх навчання;

- керівники нижчої ланки - надають пропозиції щодо вдосконалення, мотивації виробничого персоналу, підтримують дисципліну на виробничих ділянках;

- виробничий персонал - застосовують принципи концепції «Кайдзен» на індивідуальному рівні, удосконалюючи власні професійні навики, підтримують виробничу дисципліну, беруть участь у кайдзенгуртках [34].

У основі системи «Кайдзен» знаходяться 5 ключових елементів. Щоб вона могла нормально працювати та була ефективним інструментом підвищення якості, в організації необхідно створити умови для їх реалізаціі.

Перший елемент - культура вдосконалення. Усі працівники повинні розвивати себе роками. Вони мають познайомитися з компанією дуже добре і в ідеалі просуватися через усі рівні ієрархії. Це єдиний спосіб глибокого пізнання всіх процесів компанії. Крім того, лідери мають дозволяти вирішувати якісь проблеми співробітникам нижчої ланки, тобто делегувати свої повноваження та направляти інших як тренери. Успішна культура вдосконалення може призвести до підвишення продуктивності на 20 відсотків.

Другий елемент - саморозвиток. Кожен співробітник має насамперед визначити свій потенціал для подальшого зросту. Тільки якщо він вивчає поточну ситуацію та можливі потенційні помилки, тільки тоді він може досягнути наступного ступеня у ієрархії та стати керівником. Для того щоб стати керівником, співробітник має досконало розуміти операційні процеси у своїй компанії, і це також доводить, чому запрошені менеджери не можуть знаходитися на своїх позиціях довго. Знання глибинних процесів має вирішальне значення для виконання підходу, оскільки це основа для навчання інших співробітників. Крім того, керівник має бути різностороннім, оскільки він має бачити ситуацію не тільки 3 позиції компанії, а й 3 позицій клієнтів. Це може допомогти у подальшому встановленні глобальних та проміжних цілей.

Третій елемент - кваліфікація. Керівники мають побудувати свою роботу таким чином, щоб усе працювало без них. Усі співробітники мають розвиватися індивідуально. Для цього необхідно дозволяти їм вирішувати проблеми самостійно, що має призводити до постійного вдосконалення. Орієнтація на систему навчання-вирішення проблем, а не систему навчання-робота з викладачем. Але процес вирішення проблем має бути стандартизований у часі, що має призвести до швидкого зворотного зв'язку, а отже і до швидких успіхів у навчанні.

Четвертий елемент - гемба. Простір, у якому й виконується уся основна робота: виробництво, склад, офіс тощо. Усі рішення мають прийматися у безпосередній близькості до гемби, щоб керівник міг відчути себе на місці працівників. Для кращого процесу управління керівник має знаходитися і працювати безпосередньо біля своїх підлеглих.

П'ятий елемент - Хошин Канрі. Довгострокові цілі мають бути пріоритетними. Короткострокові цілі не можуть впливати на довгострокові таким чином, щоб останні були змінені. Керівник має поставити конкретну ціль перед окремим працівником, щоб сприяти адекватному розвитку як процесів, так і самих працівників [35].

У процесі вивчення системи «Кайдзен» стосовно медичної галузі було виявлено десять принципів, на які необхідно орієнтуватися при впровадженні їі у медичних організаціях:

1. Концентрація на пацієнтах;

2. Безперервні зміни невеликими кроками;

3. Відкрите визнання проблем;

4. Пропаганда відкритості;

5. Створення робочих команд.

6. Управління проектами за допомогою функціональних команд;

7. Формування підтримуючих відносин;

8. Розвиток самодисципліни;

9. Інформування кожного працівника;

10. Делегування повноважень кожному працівнику [36].

Висновки й пропозиції. Як показує світовий досвід і тенденції розвитку сучасних організацій, японська система управління довела свою унікальність та ефективність за рахунок конкретних стратегій та інструментів [15]. Усе більше та більше компаній у світі переходять на стратегію «Кайдзен», активно використовують систему покращення процесів. Такі підходи можуть використовуватися і у діяльності медичних організацій в Україні, та це питання має бути ще більше проаналізоване, вивчене та впроваджене у реальній медичній установі з урахуванням специфіки діяльності у сфері охорони здоров’я. 


\section{Список використаної літератури:}

1. Кокорева O.O. Застосування філософії Кайдзен для сучасного управління компаніями / O.O. Кокорева, B.M. Сасієв // Молодий вчений. - 2016. - №26. - С. 312-315 [Електронний ресурс]. - Режим доступу : https://moluch.ru/archive/130/36195/.

2. Закон України Про державні фінансові гарантії медичного обслуговування населення // Відомості Верховної Ради України, 2018, № 5, ст. 31 [Електронний ресурс]. - Режим доступу : zakon.rada.gov.ua/go/2168-19.

3. Gromtseva O.V. Problems of management in the new economic environment on the example of primary health care reform in Ukraine / O.V. Gromtseva // II International Scientific Conference Development of Socio-Economic Systems in a Global Competitive Environment : Conference Proceedings, May 24th, 2019. - France, Le Mans : Baltija Publishing. -129 p.

4. Imai M. Kaizen The Key to Japan's Competitive Success / M.Imai. - New York : McGraw-Hill Education, 1986.

5. Коб'єл К. Мотивація в стилі ЕКШН. Захват заразливий / К.Коб'єл. - пер. 3 німец. - М. : Альпіна Паблішер, 2011. - $192 \mathrm{c}$.

6. Маурер Р. Крок за кроком до досягнення цілі: метод кайдзен / Р.Маурер. - пер. з англ. - М. : Альпіна Паблішер, 2014. - $192 \mathrm{c}$.

7. Качалай B.B. Кайдзен-костінг: японський підхід до управління витратами на промислових підприємствах України / В.В. Качалай // Региональная экономика и управление: электронный научный журнал. - № 1 (33). 2013 [Електронний ресурс]. - Режим доступу : http://eee-region.ru/article/3301.

8. Садченко Є.В. Особливості «кайдзен» підходу до управління природовикористанням / С.B. Садченко // Економічні інновації : зб. наук. праць. - Одеса : ІПРЕЕД НАН України. - 2011. - № 42. - С. $220-232$.

9. Печориия С.В. Інноваційні технології у готельному бизнесі : монографія / С.В. Печориия - СПб. : СПбГУСЕ. 2013. $-28 \mathrm{c}$.

10. Wandel im Gesundheitswesen: Analyse der Auswirkungen auf Ärzte und Patienten am Beispiel der Ukraine / Y.Bogodistov, F.M. Reck, J.Moormann, O.P Krupskyi // Das Gesundheitswesen [Electronic recourse]. - Access mode : doi:10.1055/a-0894-4775.

11. Данченко О.Б. Моделі стратегічного менеджменту медичних проектів проектно-орієнтованого медичного закладу / О.Б. Данченко, В.В. Лепський // Вісник Національного технічного університету «ХПІ». Серія : Стратегічне управління, управління портфелями, програмами та проектами. - Харків : НТУ «ХПІ», 2018. № 2 (1278). - C. 45-52.

12. Урсол Г.М. Організаційні та психологічні аспекти оптимізації наднормового стаціонарного ліжкового фонду медичних закладів: досвід Кіровоградської області / Г.М. Урсол, О.А. Скрипник, О.М. Василенко // ScienceRise: Medical Science. - 2016. - № 5. - C. 45-50.

13. Гринів Л.В Удосконалення менеджменту поліклінічних закладів в умовах проведення медичної реформи в Україні. Масові міждержавні трудові міграції як визначальна ознака сучасної глобалізації / Л.В. Гринів, T.B. Пушик // Вісник Прикарпатського університету «Економіка». - 2018. - № XIII. - С. 130-136.

14. Hromtseva $D$. Professional culture and security: an innovative approach to implementing a medical facility / D.Hromtseva, O.Krupskyi // European Journal of Management. - 2015. - Issue 23 (5). - P. 15-23 [Electronic recourse]. - Access mode : doi:10.15421/191517.

15. Використання концепції Kaizen у діяльності медичної організації / Н.Ф. Князюк, І.С. Кіиул, М.С. Сасіна, T.В. Гуршпон // Менеджер охорони здоров’я. - 2012. - № 8. - С. 6-14.

16. Сігідов Ю.І. Еволюційний характер розвитку системи кайдзен: історичний та предметно-універсальний підходи / Ю.І. Сігідов, М.С. Рибянцева, А.С. Моісєєнко // Фінансова аналітика: проблеми та рішення. - 2013. № 48. - C. 20-30.

17. Карась E. Використання філософії «кайдзен» як сучасної практики в управлінні підприємством / E.Карась. Польща [Електронний ресурс]. - Режим доступу : http://ena.lp.edu.ua/bitstream/ntb/11950/1/104.pdf.

18. Chiarini A. Lean production, Toyota Production System and Kaizen philosophy / A.Chiarini, C.Baccarani, V.Mascherpa // The TQM Journal. - 2018. - № 30 (4). - P. 425-438 [Electronic recourse]. - Access mode : doi:10.1108/tqm-12-2017-0178.

19. Кісєльова $\epsilon$. Практичний посібник з впровадження методу Кайдзен на підприємствах Узбекістану / Є.Кісєльова, М.Мірзаджанов, Д.Нурбаєв / під заг. ред. к.е.н. А.Е. Шайхова. - Ташкент : Baktria press, 2014. - 60 c.

20. Кузнєцов М.Ю. Загальне управління якістю : учбовий посібник / М.Ю. Кузнєцо. - Тюмень : Видавництво Тюменського державного університету, 2009. - 239 с. [Електронний ресурс]. - Режим доступу : http://www.klubok.net/pageid605.html.

21. Черепанова Ю.О. Організація бережливого виробництва в охороні здоровя / Ю.О. Черепанова // Економічні науки та прикладні дослідження : зб. наук. праць ХІІ Всеросійської наук.-практ. конф. - Томск, 2015. - С. $473-477$ [Електронний ресурс]. - Режим доступу : http://earchive.tpu.ru/bitstream/11683/15462/1/conference_tpu-2015-C40V2-091.pdf.

22. Костенко T. Використання переваг системи кайдзен для підвищення продуктивності праці / T.Костенко // Вісник КНУ ім. Т.Шевченко. - 2013. - № 10 (151). - С. 122-126 [Електронний ресурс]. - Режим доступу : https://cyberleninka.ru/article/n/ispolzovanie-preimuschestv-sistemy-kaydzen-dlya-povysheniya-proizvoditelnosti-truda.pdf. 
23. Ребуха Л.3. Національний характер як формовияв національної ідеї / Л.3. Ребуха // Науковий вісник Львівського державного університету внутрішніх справ. Серія : психологічна. - 2012. - № 2 (2). - С. 53-62 [Електронний ресурс]. - Режим доступу : http://nbuv.gov.ua/UJRN/Nvldu_2012_2(2)_9.

24. Рашидова A.E. Порівняльний аналіз використання соціальних ресурсів у США та Японії / A.E. Рашидова // Сучасні гуманітарні дослідження. - 2009. - №1. - С. 195-201.

25. Терещенко Н.В. Особливості трудового менталітету української нації / Н.В. Терещенко // Історико-політичні студіï. - 2015. - № 1. - С. 76-82 [Електронний ресурс]. - Режим доступу : http://nbuv.gov.ua/UJRN/ipc_2015_1_12.

26. Гранько О. Кайдзен та Total Quality Management - японський метод управління / О.Гранько // РМ Решения. 2017 [Електронний ресурс]. - Режим доступу : https://worksection.com/blog/kaizen.html).

27. Yin Y. The evolution of seru production systems throughout Canon / Y.Yin, I.Kaku, K.E. Stecke // Operations Management Education Review. - 2008. - № 2 (1). - P. 27-40.

28. David A.J. The customer/supplier relationship - the Nissan way / A.J. David // Total Quality Management. - 1990. № 1 (1). - P. 59-68.

29. Hansen M.T. From CMMI and Isolation to Scrum, Agile, Lean and Collaboration / M.T. Hansen, Baggesen // 2009 Agile Conference.

30. Чуланова О.Л. Застосування технології Кайдзен в управлінні персоналом / О.Л. Чуланова // Світ науки. 2014. - № 4. - C. 56-64.

31. Teeuwen B. Lean for the public sector: The pursuit of perfection in government services / B.Teeuwen // Productivity Press. - 2018.

32. Менеджмент якості [Електронний ресурс]. - Режим доступу : https://www.kpms.ru/General_info/Kaizen.htm.

33. Hromtseva $O$. Japanese «KAIZEN» Concept as a Practice to Improve the Activities of Medical Institutions in Reforming Conditions / O.Hromtseva, V.Striukov // Europe Journal of Economic Research. - 2017. - Vol. 2 (2). - P. 4-10.

34. Шашина M.B. Застосування концепції кайдзен менеджменту для підвищення ефективності діяльності вітчизняних підприємств / М.В. Шашина // Агросвіт. - 2018. - № 7. - С. 26-30.

35. Dombrowski U. Lean Leadership - 15 Rules for a Sustainable Lean Implementation / U.Dombrowski, T.Mielke // Procedia CIRP. - 2014. - № 17. - P. 565-570.

36. Белих Є.B. Технологія бережливого виробництва та якості медичної допомоги. Динаміка показників / Є.В. Белих - Воронеж, 2016. [Електронний ресурс]. - Режим доступу : https://docplayer.ru/58602663Tehnologiya-berezhlivogo-proizvodstva-i-kachestvo-medicinskoy-pomoshchi-dinamika-pokazateley.htm.

\section{References:}

1. Kokoreva, O.O., Sasiiev, V.M. (2016), «Zastosuvannia filosofii Kaidzen dlia suchasnoho upravlinnia kompaniiamy», Molodyi vchenyi, No. 26, pp. 312-315, [Online], available at: https://moluch.ru/archive/130/36195/

2. Verkhovna Rada Ukrainy (2018), Zakon Ukrainy Pro derzhavni finansovi harantii medychnoho obsluhovuvannia naselennia, Vidomosti Verkhovnoi Rady Ukrainy, No. 5, stattja 31, [Online], available at: http://zakon.rada.gov.ua/go/2168-19

3. Gromtseva, O.V., (2019), «Problems of management in the new economic environment on the example of primary health care reform in Ukraine», II International Scientific Conference Development of Socio-Economic Systems in a Global Competitive Environment, Conference Proceedings, May 24th, Baltija Publishing, Le Mans, France, 129 p.

4. Imai, M. (1986), Kaizen The Key to Japan's Competitive Success, McGraw-Hill Education, New York

5. Kobell, K. (2011), Motyvacija v styli EKShN. Zahvat zarazlyvyj, transl. from German, Alpina Publisher, Moscow, 192 p.

6. Maurer, R. (2014), Krok za krokom do dosiahnennia tsili: metod kaidzen, transl. from English, Alpina Publisher, Moscow, $192 \mathrm{p}$.

7. Kachalai, V.V. (2013), «Kaidzen - kostinh: yaponskyi pidkhid do upravlinnia vytratamy na promyslovykh pidpryiemstvakh Ukrainy», Regional economics and management: electronic scientific journal, No. 1 (33), [Online], available at: http://eee-region.ru/article/3301

8. Sadchenko, Ye.V. (2011), «Osoblyvosti «kaidzen» pidkhodu do upravlinnia pryrodovykorystanniam», Ekonomichni innovatsii: zb. nauk. pr., IPREED NAN Ukrainy, Odesa, No. 42, pp. 220-232.

9. Pechorytsia, Ye.V. (2013), Innovatsiini tekhnolohii u hotelnomu byznesi, monografija, SPbHUSE, Sankt-Peterburg, 128 p.

10. Bogodistov, Y., Reck, F.M., Moormann, J., and Krupskyi, O.P. (2019), «Wandel im Gesundheitswesen: Analyse der Auswirkungen auf Ärzte und Patienten am Beispiel der Ukraine», Das Gesundheitswesen, [Online], available at: doi:10.1055/a-0894-4775

11. Danchenko, O.B. and Leps'kyi, V.V. (2018), «Modeli strategichnogo menegmentu medichnih proektiv proektnoorientovanogo medichnogo zakladu», Visnik Natsionalnogo technichnogo universitetu "KhPI», Seria Strategichne upravlinnya, upravlinnya portfelyami, programmami ta proektami, No. 2 (1278), pp. 45-52.

12. Ursol, G.M., Skrypnik, O.A. and Vasylenko, O.M. (2016), «Organizaciini ta psychologichni aspekty optymizacii nadnormovogo stacionarnogo lijkovogo fondu medichnych zakladiv: dosvid kirovogradskoi oblast», Science Rise: Medical Science, No. 5, pp. 45-50.

13. Hryniv, L.V. and Pushik, T.V. (2018), «Udoskonalennya menegmentu poliklinichnych zakladiv v umovach provedennya medichnoi reformy v Ukraini. Masovi mijderjavni trudovi migracii yak vyznachalna oznaka suchasnoi globalizacii», Visnyk Prikarpatskogo universitetu Economica, No. XIII, pp. 130-136. 
14. Hromtseva, D. and Krupskyi, O. (2015), «Professional culture and security: an innovative approach to implementing a medical facility», European Journal of Management, Issue 23 (5), pp. 15-23, [Online], available at: doi:10.15421/191517

15. Kniaziuk, N.F., Kitsul, I.S., Sasina, M.S. and Hurshpon, T.V. (2012), «Vykorystannia kontseptsii Kaizen u diialnosti medychnoi orhanizatsii», Menedzher okhorony zdorovia, No. 8, pp. 6-14.

16. Sihidov, Yu.I., Rybiantseva, M.S. and Moisieienko, A.S. (2013), «Evoliutsiinyi kharakter rozvytku systemy kaidzen: istorychnyi ta predmetno-universalnyi pidkhody», Finansova analityka: problemy ta rishennia, No. 48, pp. 20-30

17. Karas, E. (2010), Vykorystannia filosofii «kaidzen» yak suchasnoi praktyky v upravlinni pidpryiemstvom, Poland, [Online], available at: http://ena.lp.edu.ua/bitstream/ntb/11950/1/104.pdf

18. Chiarini, A., Baccarani, C. and Mascherpa, V. (2018), «Lean production, Toyota Production System and Kaizen philosophy», The TQM Journal, No. 30 (4), pp. 425-438, [Online], available at: doi:10.1108/tqm-12-2017-0178

19. Kisielova, Ie., Mirzadzhanov, M. and Nurbaiev D. (2014), Praktychnyi posibnyk z vprovadzhennia metodu Kaidzen na pidpryiemstvakh Uzbekistanu, in Shaikhova, A.E. (ed), Baktria press, Tashkent, 60 p.

20. Kuznietsov, M.Yu. (2009), Zahalne upravlinnia yakistiu, uchbovyi posibnyk, Vydavnytstvo Tiumenskoho derzhavnoho unyversytetu, Tiumen, 239 p., [Online], available at: http://www.klubok.net/pageid605.html

21. Cherepanova, Yu.O. (2015), «Orhanizatsiia berezhlyvoho vyrobnytstva v okhoroni zdorovia», zbirnyk naukovykh prats XII Vserosiiskoi nauk.-prakt. konf. Ekonomichni nauky ta prykladni doslidzhennia, Tomsk, pp. 473-477, [Online], available at: http://earchive.tpu.ru/bitstream/11683/15462/1/conference_tpu-2015-C40-V2-091.pdf

22. Kostenko, T. (2013), «Vykorystannia perevah systemy kaidzen dlia pidvyshchennia produktyvnosti pratsi», Visnyk $K N U$ im. T.Shevchenko, No. 10 (151), pp. 122-126, [Online], available at: https://cyberleninka.ru/article/n/ispolzovaniepreimuschestv-sistemy-kaydzen-dlya-povysheniya-proizvoditelnosti-truda.pdf

23. Rebukha, L.Z. (2012), «Natsionalnyi kharakter yak formovyiav natsionalnoi idei», Naukovyi visnyk Lvivskoho derzhavnoho universytetu vnutrishnikh sprav, seriia psykholohichna, No. 2, pp. 53-62, [Online], available at: http://nbuv.gov.ua/UJRN/Nvldu_2012_2(2)_9

24. Rashydova, A.E. (2009), «Porivnialnyi analiz vykorystannia sotsialnykh resursiv u SShA ta Yaponii», Suchasni humanitarni doslidzhennia, No. 1, pp. 195-201.

25. Tereshchenko, N.V. (2015), «Osoblyvosti trudovoho mentalitetu ukrainskoi natsii»»», Istoryko-politychni studii, No. 1, pp. 76-82, [Online], available at: http://nbuv.gov.ua/UJRN/ipc_2015_1_12

26. Hranko, O. (2017), «Kaidzen ta Total Quality Management - yaponskyi metod upravlinnia», [Online], available at: https://worksection.com/blog/kaizen.html

27. Yin ,Y., Kaku, I. and Stecke, K.E. (2008), «The evolution of seru production systems throughout Canon», Operations Management Education Review, No. 2 (1), pp. 27-40.

28. David, A.J. (1990), «The customer/supplier relationship - the Nissan way», Total Quality Management, No. 1 (1), pp. 59-68.

29. Hansen, M.T. and Baggesen (2009), «From CMMI and Isolation to Scrum, Agile, Lean and Collaboration», 2009 Agile Conference.

30. Chulanova, O.L. (2014), «Zastosuvannia tekhnolohii Kaidzen v upravlinni personalom», Svit nauky, No. 4, pp. 56-64.

31. Teeuwen, B. (2018), «Lean for the public sector: The pursuit of perfection in government services», Productivity Press.

32. Menedzhment yakosti, [Online], available at: https://www.kpms.ru/General_info/Kaizen.htm

33. Hromtseva, O. and Striukov, V. (2017), «Japanese "KAIZEN" Concept as a Practice to Improve the Activities of Medical Institutions in Reforming Conditions», Europe Journal of Economic Research, Vol. 2( 2), pp. 4-10.

34. Shashyna, M.V. (2018), «Zastosuvannia kontseptsii kaidzen menedzhmentu dlia pidvyshchennia efektyvnosti diialnosti vitchyznianykh pidpryiemstv», Ahrosvit, No. 7, pp. 26-30.

35. Dombrowski, U. and Mielke, T. (2014), «Lean Leadership - 15 Rules for a Sustainable Lean Implementation», Procedia CIRP, No. 17, pp. 565-570.

36. Belyh, Je.V. (2016), Tehnologija berezhlyvogo vyrobnyctva ta jakosti medychnoi' dopomogy. Dynamika pokaznykiv, Voronezh, [Online], available at: https://docplayer.ru/58602663-Tehnologiya-berezhlivogo-proizvodstva-i-kachestvomedicinskoy-pomoshchi-dinamika-pokazateley.html

Громцева Олена Віталіївна - аспірант, заступник головного лікаря Центру Первинної МедикоСанітарної Допомоги м. Підгороднє.

E-mail: fufushka@meta.ua.

https://orcid.org/0000-0001-8353-4638

Стрюков Василь Васильович - аспірант, викладач Комунального вищого навчального закладу «Дніпровський базовий медичний коледж».

E-mail: fap.ua@ukr.net.

https://orcid.org/0000-0002-5463-3124. 